\title{
Flood and Inundation Forecasting in the Sparsely Gauged Transboundary Chenab River Basin Using Satellite Rain and Coupling Meteorological and Hydrological Models
}

\author{
MALIK RIZWAN ASGHAR \\ Flood Forecasting Division, Pakistan Meteorological Department, Lahore, Pakistan
}

TOMOKI USHIYAMA

International Center for Water Hazard and Risk Management, Public Works Research Institute, Tsukuba, Japan

MUHAMMAD RiAZ

Flood Forecasting Division, Pakistan Meteorological Department, Lahore, Pakistan

MAMORU MIYAMOTO

International Center for Water Hazard and Risk Management, Public Works Research Institute, Tsukuba, Japan

(Manuscript received 2 November 2018, in final form 24 September 2019)

\begin{abstract}
Flood forecasting in a transboundary river basin is challenging due to insufficient data sharing between countries in the upper and lower reaches of a basin. A solution is the use of satellite-observed rainfall and numerical weather prediction (NWP) for hydrological forecasting. We applied this method to the transboundary sparsely gauged Chenab River basin in Pakistan and India to reproduce the exceptionally high flood in 2014. We employed global NWPs by three weather centers to consider forecast uncertainty and downscaled them using the Weather Research and Forecasting (WRF) Model to prepare precipitation inputs. For hydrological simulations, we used a kinematic wave model, the Integrated Flood Analysis System (IFAS), for the upper-reach basin with high mountains and steep slopes, and we used a diffusive-wave rainfall-runoff-inundation (RRI) model for low altitudes and mild slopes. In our forecasting experiment, the precipitation by the global NWP was not able to predict flood peaks consistently. However, the downscaled rainfall by regional NWP showed good performance in predicting flood waves quantitatively, and a multimodel approach provided added value in issuing reliable warning as early as 6 days in advance. A confident streamflow forecasting near the border of the countries also led to reliable inundation forecasting by the RRI model in the lower-reach basin.
\end{abstract}

\section{Introduction}

Severe rainfall events have become more common in recent years (Lehmann et al. 2015), leading to catastrophic floods and huge life, infrastructure, and economic losses, and they are expected to be even more frequent due to global warming (Hirabayashi et al. 2013). In these circumstances, the demand for hydrometeorological forecasting and early warning has been increasing for more effective risk management. However, in transboundary river basins, which spread over two or more countries, flood forecasting is rather

Corresponding author: Malik Rizwan Asghar, mrmkhokhar@ gmail.com difficult since upstream countries tend not to share hydrological data such as water levels or precipitations with downstream countries (Hossain et al. 2007). Transboundary eastern tributaries of the Indus River lying in Pakistan and India suffered from a devastating flood disaster in 2014. Conventional flood forecasting systems using rain gauges and river water gauges could not mitigate disaster damage effectively due to the short traveling time of the flood within the downstream country of Pakistan.

Precipitation data from satellites and numerical weather prediction (NWP) are promising solutions to implement flood forecasting in downstream countries (Hossain et al. 2007). As satellite derived precipitation, various kinds of precipitation products are provided over 
the globe in the framework of the Global Precipitation Measurement (GPM) mission (Hou et al. 2014). One of the products is the Global Satellite Mapping of Precipitation (GSMaP) provided by the Japan Aerospace Exploration Agency (JAXA) (Okamoto et al. 2005; Kubota et al. 2009). It has an advantage of the highest temporal interval $(1 \mathrm{~h})$ and the highest horizontal resolution $\left(0.1^{\circ}\right)$. Although it has a significant bias in highaltitude regions such as the Himalayas (Shrestha et al. 2011) or the upper Indus River (Ushiyama et al. 2014), GSMaP is useful for hydrological forecasting in ungauged regions.

NWP is vital to achieve flood forecasting with a sufficient lead time. The combination of NWP and hydrological forecasting are intensively studied especially in Europe (e.g., Cloke and Pappenberger 2009; Cuo et al. 2011; Alfieri et al. 2013). Streamflow observations, as well as meteorological and hydrological forecasts of the rivers, are shared among countries along the international rivers in the region. They have established the European Flood Awareness System (EFAS) to provide various data including streamflow forecasts, based on an ensemble prediction system managed by the European Centre for Medium-Range Weather Forecasts (ECMWF). EFAS also utilizes downscaling of the ensemble prediction system to $7 \mathrm{~km}$ (Thielen et al. 2009). They have expanded the applications of EFAS over the globe as the Global Flood Awareness System (GLOFAS), which is useful in ungauged basins around the world (Alfieri et al. 2013). GLOFAS successfully reproduced the 2010 devastating flood in the main Indus River in Pakistan. Webster et al. (2010) demonstrated a possible streamflow forecasting capability up to a lead time of 10-15 days in Bangladesh in 2007 and 2008 by the combination of ECMWF ensemble forecasting and hydrological forecasting. Haile et al. (2016) applied a similar method to the NigerBenue basin and obtained promising results. However, they mainly used global NWP, and their downscaling was applied only to Europe.

The downscaling of global NWP by regional models effectively improves forecasting especially in small river basins or mountainous regions by considering more realistic topography and atmospheric circulations (Davolio et al. 2008; Roberts et al. 2009; Yan and Gallus 2016; Yu et al. 2016). As computational power and observational data quality and quantity improve, the quantitative precipitation forecasting (QPF) by NWP has substantially increased in their capability. Bartholmes and Todini (2005) conducted research employing the combinations of precipitation forecasts by mesoscale atmospheric models of different resolutions with a distributed hydrological model (DHM) while also taking into account clarified limitations and uncertainties to be considered in the application of real-time flood forecasting. Ushiyama et al. (2014) demonstrated the validity of the streamflow and inundation forecasting in the Kabul River basin, located in the western tributary of the Indus River basin, by using QPF downscaled from the Global Forecast System (GFS) of the National Centers for Environmental Prediction (NCEP).

The Chenab River basin (CRB), one of the tributaries of the Indus River in the eastern central part of Pakistan, suffered tremendous damage from an exceptionally high flood in September 2014. Floodwaters overtopped and breached river embankments, affecting several hundred villages in many districts of Punjab Province. A few villages were completely submerged, and several people were killed. The catastrophic flooding caused huge infrastructural and economic losses, as reported by the media and also explained by Rahman et al. (2017).

To minimize losses and facilitate efficient relief and evacuation processes, effective flood forecasting and early warning with a sufficient lead time are desired in such transboundary basins. However, little has been addressed about flood forecasting in transnational basins in south Asia including Pakistan. To enhance the reliability of flood forecasting, we examined multiple global NWPs and their downscaling by the Weather Research and Forecasting (WRF) Model (Skamarock et al. 2005). We also utilized the GSMaP satellite observed rainfall to run a hydrological model beforehand, after their biases were corrected based on ground rain gauges. For the hydrological component, we applied two types of models. For the upper-reach mountainous area, the Integrated Flood Analysis System (IFAS) (Sugiura et al.2010), a kinematic wave approximation model, was applied to reduce computational time. For the lowerreach flat area, the rainfall-runoff-inundation (RRI) model (Sayama et al. 2012), a diffusive wave approximation model, was applied to simulate inundation.

The following questions were addressed in this study:

1) How effective is bias-corrected satellite rainfall in calibrating hydrological models for transboundary basins?

2) How effective are precipitation forecasts by global NWP to produce flood peaks by a hydrological model?

3) How reliable can flood, inundation, and early warning decisions be, when made based on satellite rainfall and downscaled precipitation forecasts from three different global models?

This paper details the study area in section 1 and the flood event in section 2. The methodology is explained in section 3 along with the domain settings of the WRF 


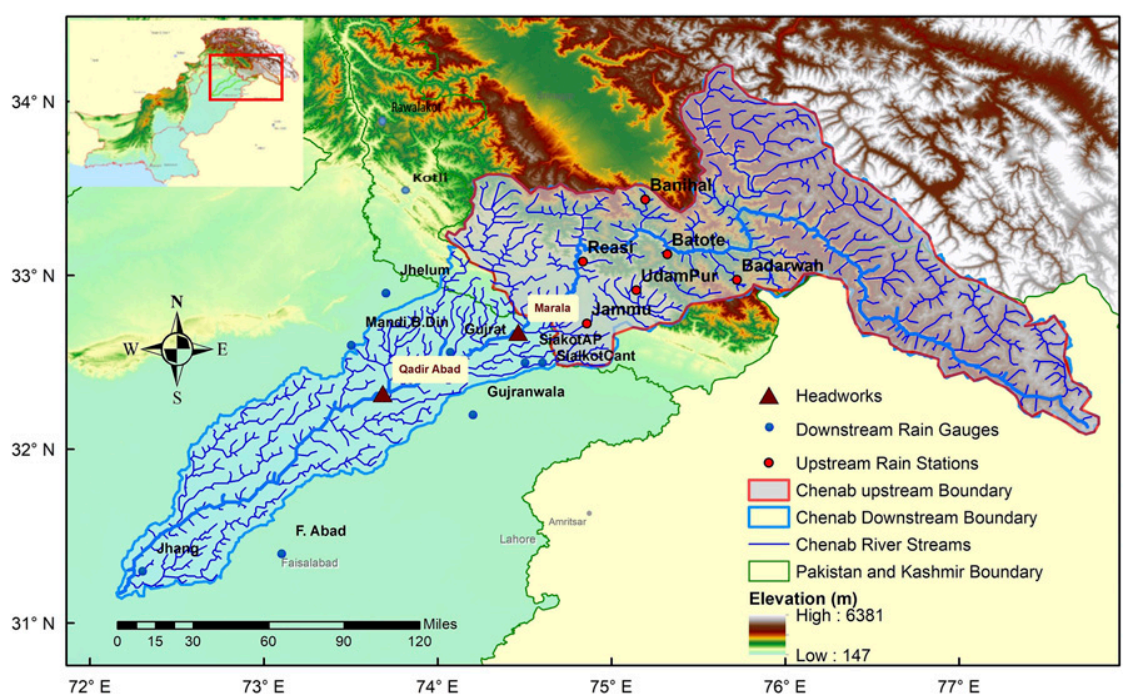

FIG. 1. Location and elevation map of the Chenab River basin showing upstream and downstream areas.

model and the descriptions of the IFAS and RRI models. Section 4 presents the results and discussions, and finally the conclusions are summarized in section 5 .

\section{Study area and flood in 2014}

The geographical location and elevations of the Chenab River basin are shown in Fig. 1. The Chenab River is the eastern tributary of the Indus River system and originates in the Himalaya Mountains of India. It flows in a zigzag path of steep slopes through Kashmir in the west-northwest direction, later turning to the southwest and finally entering the plains of mild slopes in Punjab Province of Pakistan to the southwest. The river width varies from 700 to $1400 \mathrm{~m}$ with flood plains much wider than the river. The Marala headworks is the first water discharge measuring station in Pakistan near the border of the Pakistan and India. It is also called a rim station, from which the river flows into the planes of Punjab. The total area of the river basin, located upstream of the Trimmu headworks, is about $46000 \mathrm{~km}^{2}$, out of which $28000 \mathrm{~km}^{2}$ lies upstream of the rim station. The upper Chenab River is mostly mountainous with varying steep slopes, and the altitude range exceeds $6000 \mathrm{~m}$, though the slope downstream of the rim station is mild, about $1 / 2500$ (Awan 2003).

The flood season starts in summer (15 June-15 October); the Indian summer monsoon system is the major rainfall contributor in the study area, which is under an active core monsoon belt. Its upstream basin receives snow during the winter, and the snowmelt contributes to the river base flow until the early days of the monsoon. In the later months, the impact of snowmelt is minor and does not play a significant role in causing a flood. The Himalaya Mountains, located north of the Marala headworks, provide suitable conditions for orographic lifting to the monsoon current penetrating from the Bay of Bengal and the Arabian Sea, resulting in heavy rainfall on the windward side, which contributes to a huge increase in streamflow leading to disastrous floods (Awan 2003; Ray et al. 2015).

According to the criteria defined by the Flood Forecasting Division (FFD) of the Pakistan Meteorological Department (PMD), an exceptionally high flood is likely to occur at the Marala headworks of the Chenab River when the discharge exceeds $17000 \mathrm{~m}^{3} \mathrm{~s}^{-1}$. The same criteria has been identified by Awan (2003). The criteria and thresholds for low, medium, and high floods are given in Fig. 2. The threshold limits are given in cubic meter per second and rounded to the nearest hundred for clear understanding.

Majid and Akhtar (2007) explained that severe flooding occurs in the study river when a tropical storm originating in the Bay of Bengal and approaching the upper Indus River system comes under the influence of an eastward-moving westerly trough along the northern latitudes of Pakistan. Similar atmospheric conditions were present during the 2014 flood, when two low pressure areas over central India and Gujrat merged together and the system moved northwest of India under the presence of a midtropospheric trough. A prolonged spell of heavy rainfall in the first week of September 2014 was caused by a synoptic meteorological situation due to the interaction of a monsoon low with a deep westerly trough extending to midlatitudes, as discussed by Ray et al. (2015). Most of the rainfall 


\begin{tabular}{|c|c|c|c|}
\hline Flood State & Color & Threshold( $\left.\mathbf{m}^{3} / \mathbf{s}\right)$ & Description of water flow \\
\hline Low & & 2800 & Flow in main channel may spill over Sandbars/Islands \\
\hline Medium & & 4200 & Partly inundating Sandbars/Islands \\
\hline High & & 5600 & Fully submerged Islands/Sandbars, flow in flood plain. \\
\hline Very High & & 11300 & $\begin{array}{l}\text { Flow between embankments/bands, advancing to } \\
\text { unprotected lands }\end{array}$ \\
\hline Exceptionally & & 17000 & Danger of over topping/Breaching or breaching has \\
\hline High & & & already occurred. \\
\hline
\end{tabular}

FIG. 2. Criteria, thresholds, and color coding of floods at Marala headworks in CRB.

occurred in southwestern Kashmir and its adjoining Punjab Province of Pakistan, located in the upper basins of the Chenab and Jhelum rivers. Extreme rainfall in the upper basins raised the water levels in the river channels at 1200 UTC 3 September 2014. Continuous rainfall for three consecutive days led to an exceptionally high flood in the river, and the discharge reached a peak of more than $22000 \mathrm{~m}^{3} \mathrm{~s}^{-1}$ at the Marala headworks at 1800 UTC 6 September 2014. The discharge peak then shifted to the Qadir Abad headworks along with the lateral flow contribution from slopes downstream of Marala, and a peak discharge of $25000 \mathrm{~m}^{3} \mathrm{~s}^{-1}$ was observed at 1200 UTC 7 September 2014, approximately $18 \mathrm{~h}$ after the peak observed at Marala.

\section{Methodology}

We conducted an experimental flood forecasting study using rainfall from NWP and hydrological models. Forecasted rainfall or QPF data were employed from the global NWP in NCEP, ECMWF, and the Japan Meteorological Agency (JMA) with various initial times. We also examined QPF downscaled by those three weather centers using a regional model, Advanced Research WRF version 3.4.1. We examined different forecasts with six initial times between 0000 UTC 1 September and 1200 UTC 3 September 2014, with an interval of $12 \mathrm{~h}$. Those QPF data were supplied to hydrological models, that is, IFAS and RRI, along with bias corrected satellite rainfall (where observed data was not available), to simulate the river flow in the upper reach and the inundation in the lower reach basin.

\section{a. Rainfall and discharge data}

For the lower-reach basin, storm rainfall data of eight observation stations were collected from FFD of PMD, and for the upper-reach basin, rainfall from Ray et al. (2015) was used. Accumulated storm rainfall data from 0000 UTC 3 September to 0000 UTC 7 September 2014 in the upper- and lower-reach basins are given in Fig. 3. Observed flood hydrographs at the Marala and Qadir Abad headworks are shown in Fig. 4. In the lower reach basin, downstream ground rainfall (Fig. 3) along with discharge datasets was used for the
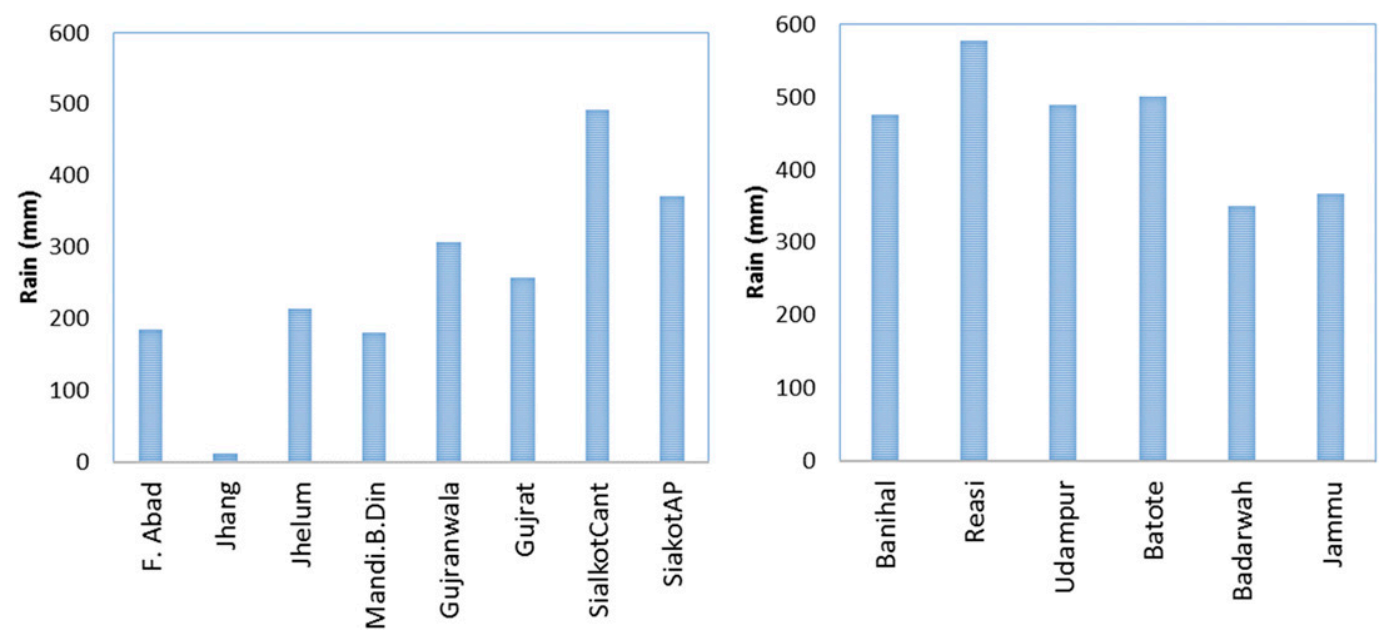

FIG. 3. Accumulated storm rainfall at (left) downstream and (right) upstream rain gauges from 0000 UTC 3 Sep 2014 to 0000 UTC 7 Sep 2014. 


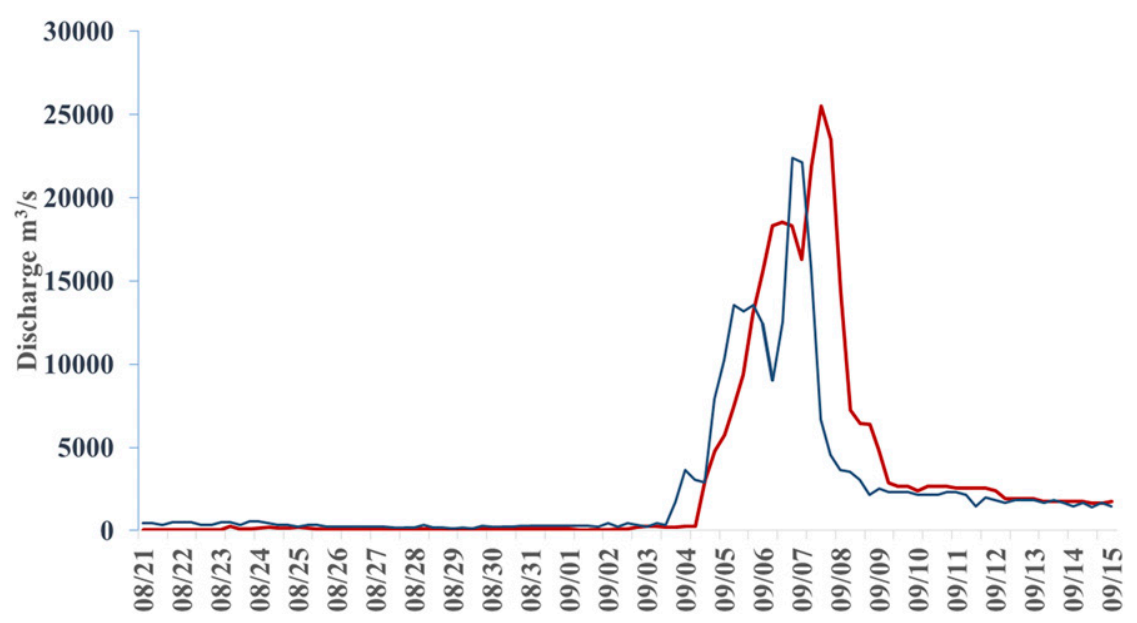

FIG. 4. Observed hydrographs at Marala headworks (blue line) and Qadir Abad (brown line) for the flood event of September 2014 in the Chenab River basin.

calibration and validation of the hydrological model used for the area downstream of the rim station.

Since the upper CRB is transnational and thus ground observations are not available in real time, satellite rainfall was the ultimate option to rely on. The GSMaP Gauge calibrated product (GSMaP-Gauge) explained by Ushio et al. (2013) was used for hydrological model calibration and real-time river flow simulations.

The GSMaP-Gauge rainfall in the CRB for the storm event of 2014 was much less than the observed ground rainfall; therefore, correction was required. Since the upper reach of the basin is transnational and ground data are not available in real time, the available ground rain gauges in the east (Kotli, Rawalakot) outside the boundary of the upper reach basin were selected for the correction of the GSMaP-Gauge dataset. The daily ground rainfall means (Kotli, Rawalakot) of the flood season (15 June-15 October) were compared with the corresponding GSMaP-Gauge rainfall means to obtain daily scale factors. The daily scale factors were then applied to the GSMaP-Gauge daily data of the CRB to get desired rainfall closer to the observed rainfall in the upper reach basin (Fig. 3) and to reproduce exceptionally high flood peaks using IFAS. The bias-corrected GSMaPGauge satellite rainfall is shown in Fig. 5.

The NCEP-GFS provides forecasts in gridded binary format and is available at the NOAA National Operational Model Archive and Distribution System (NOMADS). GFS data were obtained from the NCEP server at $0.5^{\circ}$ resolution. The ECMWF, supported by the European nations, has developed a global data assimilation and forecasting system known as the Integrated Forecasting System (IFS). The ECMWF hosts the world's largest data archival system capable of providing deterministic weather forecasts for a period of up to 2 weeks. The JMA-Global Spectral Model (JMAGSM) provides global forecasts 11 days ahead. Global forecasts data of ECMWF-IFS and JMA-GSM at $0.5^{\circ}$ were obtained through the THORPEX Integrated Grand Global Ensemble (TIGGE), which holds data from 10 global models.

\section{b. WRF Model setting and global forecasts}

To obtain high-resolution QPF data, we used the WRF model, an atmospheric nonhydrostatic model, supported by the National Center for Atmospheric Research (NCAR). It has become a community model worldwide to dynamically downscale global-scale forecasts at a regional scale, as explained by Powers et al. (2017).

In this study, the dynamic solver Advanced Research version of WRF (ARW) was used for downscaling

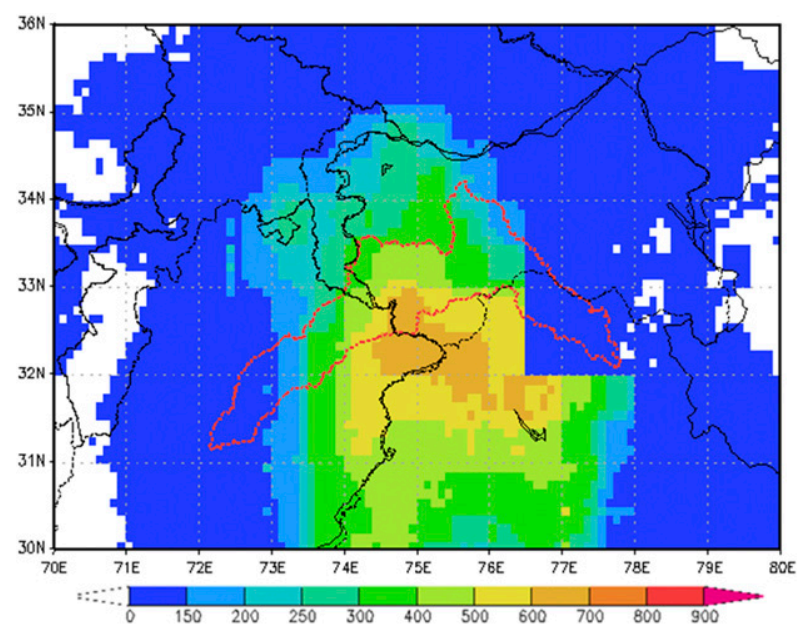

FIG. 5. Bias corrected GSMaP-Gauge accumulated storm rainfall (mm) from 0000 UTC 3 Sep 2014 to 0000 UTC 7 Sep 2014. 


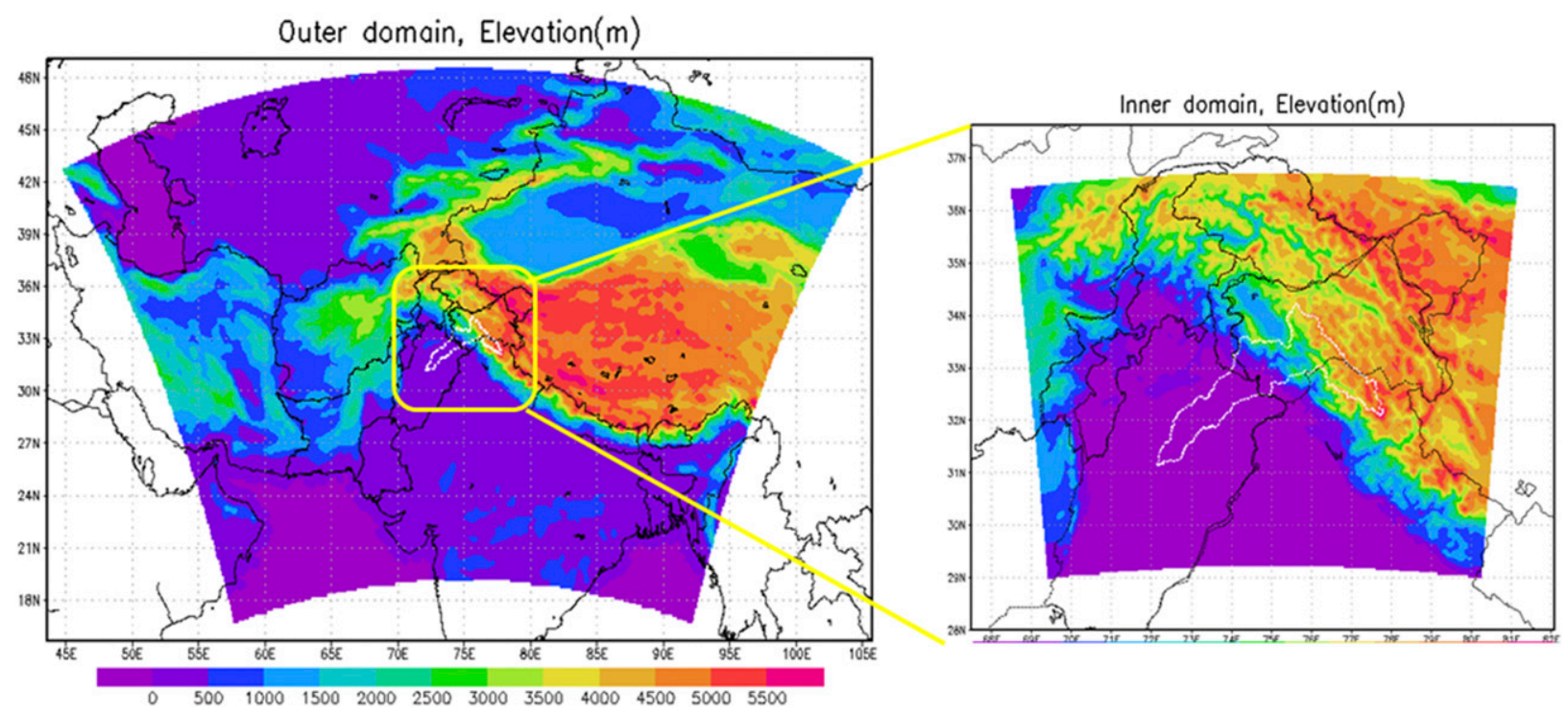

FIG. 6. Map of the model domain settings in WRF Model. It shows the elevation of the study area in the (left) outer domain of 20-km grid resolution and (right) inner domain of 5-km resolution. The shaded area shows topography, and the white dotted enclosed area in both figures represents the Chenab River basin.

the forecasts of three global-scale models, namely, NCEP-GFS, ECMWF-IFS, and JMA-GSM. A twoway nested 1:4 ratio domain was defined to keep the CRB in the center as shown in Fig. 6. The outer domain $(4400 \mathrm{~km} \times 3300 \mathrm{~km})$ was set to cover the whole Pakistan and extended to include the Bay of Bengal in the east, the Arabian Sea in the south, and the Caspian Sea in the west with a grid cell resolution of $20 \mathrm{~km}$. The inner domain $(1105 \mathrm{~km} \times 845 \mathrm{~km})$ was defined at $5-\mathrm{km}$ grid spacing to cover the CRB. The microphysics scheme proposed by Lin et al. (1983) was used to predict water vapor, cloud water, cloud ice, rain, snow, and hail. The unified Noah land surface scheme with four soil layers was used. The Kain-Fritsch cumulus scheme and the Dudhia scheme for short wave radiation were used in both domains.

The global-model forecasted precipitation data at a $0.5^{\circ}$ resolution, with six initial times between 0000 UTC 1 September and 1200 UTC 3 September 2014 , and an interval of $12 \mathrm{~h}$, were used to analyze the 2014 flood in the CRB. Global forecasts were provided as the initial and boundary conditions to WRF for dynamic downscaling at a finer resolution at a regional scale.

\section{c. Hydrological models}

IFAS was used for upper-reach discharge simulations. This model was developed for poorly gauged river basins and has been validated in several hydrological studies conducted by Sugiura et al. (2013), Aziz
(2014), Miyamoto et al. (2014), and Riaz et al. (2017) for river flow forecasting in various regions of the world. The outflow at each grid cell was calculated by nonlinear relationships based on three-layer tank models namely surface, aquifer and river tanks. Instead of being only the black box system, the nonlinear relationships were based on Manning's roughness and hyperbolic approximations. River routing was propagated through a kinematic wave hydraulic model. For the study area, the Global Land Cover data, provided by the International Steering Committee for Global Mapping (ISCGM), were divided into five categories in the IFAS model with a grid cell size of $5 \mathrm{~km}$. Sensitivity analysis was carried out to tune surface, aquifer and river parameters in order to calibrate the model. The bias-corrected GSMaP-Gauge rainfall in the upperreach basin was supplied to the calibrated model, and simulated outflow discharge at a river outlet (Marala headworks) was validated with the observed hydrograph.

Sayama et al. (2012) developed the RRI model having the capability of predicting water depth along with river routing. RRI-based inundation simulations showed good agreement with MODIS imagery in Indus and Thailand floods. To get inundation forecasts in the lower-reach CRB, RRI was set to use USGS HydroSHEDS data of 500-m resolution. The slope and river cells were handled separately in RRI; however, the slope cells overlaying on the river course had two depths: channel depth and slope depth. Inflow to and outflow from the river channel were calculated, 
depending upon water levels and embankment heights, as explained by Sayama et al. (2012). Initially the average river width was estimated from the Google imagery; then parameters in regression equations (1) and (2) were tuned, empirically, to calculate the optimum river width and depth at each river cell:

$$
\begin{gathered}
W=C_{w} A^{S_{w}}, \\
D=C_{D} A^{S_{D},}
\end{gathered}
$$

where $W$ and $D$ represent width and depth in meters, respectively. The term $A$ represents the upstream area at each grid cell $\left(\mathrm{km}^{2}\right)$, and $C_{W}, S_{W}, C_{D}$, and $S_{D}$ are geometry parameters. To calculate river flow and water depths at each grid cell, the following modified forms of momentum equations (3) and (4) and discretized mass balance equation (5) were used (Sayama et al. 2012):

$$
\begin{aligned}
& q_{x}=-\frac{1}{n} h^{5 / 3} \sqrt{\left|\frac{\partial H}{\partial x}\right|} \operatorname{sgn}\left(\frac{\partial H}{\partial x}\right), \\
& q_{y}=-\frac{1}{n} h^{5 / 3} \sqrt{\left|\frac{\partial H}{\partial y}\right|} \operatorname{sgn}\left(\frac{\partial H}{\partial y}\right), \quad \text { and } \\
& \frac{d h^{i, j}}{d t}+\frac{q_{x}^{i, j-1}-q_{x}^{i, j}}{\Delta x}+\frac{q_{y}^{i, j-1}-q_{y}^{i, j}}{\Delta y}=r^{i, j},
\end{aligned}
$$

where $h$ is the height of water from the surface in meters, $q_{x}$ and $q_{y}$ are unit discharges $\left(\mathrm{m}^{3}\right)$ in $x$ and $y$ directions, $r$ is rainfall intensity $(\mathrm{mm}), H$ is water surface height (m) from the datum, $q_{x}^{i, j}$ and $q_{y}^{i, j}$ are the $x$ and $y$ direction discharges $\left(\mathrm{m}^{3}\right)$ at grid cell location $(i, j), \operatorname{sgn}$ is the signum function, and $n$ represents Manning's roughness.

The model was supplied with the ground rainfall of the downstream basin and the observed boundary discharge at Marala. Separate land-use classes were defined for river/flood plains and slope cells. Embankments alongside the river, which are in the form of constructed levees or elevated roads, were also introduced in the model. Manning's roughness for land $(n)$ and river $\left(n_{\text {river }}\right)$ were adjusted to 0.35 and 0.03 , respectively. Water discharges at Qadir Abad, simulated using a calibrated RRI model, were compared with observed data. Water extent from 8-day composite MODIS images of 14 September 2014, was extracted using the Modified Normalized Difference Water Index (MNDWI), which was developed by Xu (2006). The MODIS extent was then compared with the RRI-based inundation downstream of the Qadir Abad headworks.

\section{Results and discussion}

\section{a. Flood forecasting by using rainfall from global forecasts}

Figure 7 shows accumulative forecasted rainfall from three different global forecasts, namely, NCEP-GFS, ECMWF-IFS, and JMA-GSM, for the period from 0000 UTC 3 September to 0000 UTC 7 September 2014, at a coarse resolution of $0.5^{\circ}$. Global weather forecasts, with six initial times between 0000 UTC 1 September and 1200 UTC 3 September 2014, and an interval of $12 \mathrm{~h}$, were selected. Almost all of the forecasts showed significant rainfall inside or near the upper reach of the $\mathrm{CRB}$ with various intensities, though showing much less rainfall than the bias-corrected GSMaP-Gauge rainfall in Fig. 5. NCEP-GFS forecasts (Fig. 7a) with the initial times of 0000 and 1200 UTC 1 September show higher intensities and cover a wider area inside the basin, while the 0000 UTC 2 September forecast covers only the eastern side of the CRB with slight rainfall. JMAGSM (Fig. 7c) shows the lowest intensity and covers a very small area inside the CRB, and, in some cases, completely fails to forecast rainfall inside the CRB. ECMWF-IFS (Fig. 7b) covers a larger area inside the basin in all the cases and is more consistent than the other two models; however, it shows a rainfall intensity lower than that of NCEP-GFS though higher than that of JMA-GSM.

To examine the applicability of global-scale precipitation forecasts to flood forecasting, the global-scale forecasts were supplied to the calibrated IFAS model. Peak discharges at the Marala headworks simulated using the NCEP-GFS forecasts are shown in Fig. 8a. The peak discharge (slightly above $20000 \mathrm{~m}^{3} \mathrm{~s}^{-1}$ ) obtained from the QPF of 0000 UTC 1 September is a good indication of a huge flood with a lead time of 6 days. But the subsequent QPFs from 1200 UTC 1 September to 0000 UTC 2 September fail to reproduce the high discharge, because the forecasted rainfall shifted eastward in the CRB. However, the later forecasts from 1200 UTC 2 September to 1200 UTC 3 September predict rainfall within the CRB with accurate intensity and thus are successful in predicting the exceptionally high flood discharge. Only three out of six forecasts $(50 \%)$ are able to exceed the very high flood threshold as per the criteria defined in Fig. 2. ECMWF-IFS are able to give consistent discharges; however, the flood peak does not reach the height of the exceptionally high flood mark (Fig. 8b). In the case of JMA-GSM, all the forecasts even remain below the high flood mark since the rainfall distribution was mostly outside the CRB (Fig. 8c). The forecast uncertainty in the coupling of global-scale precipitation forecasts and hydrological 


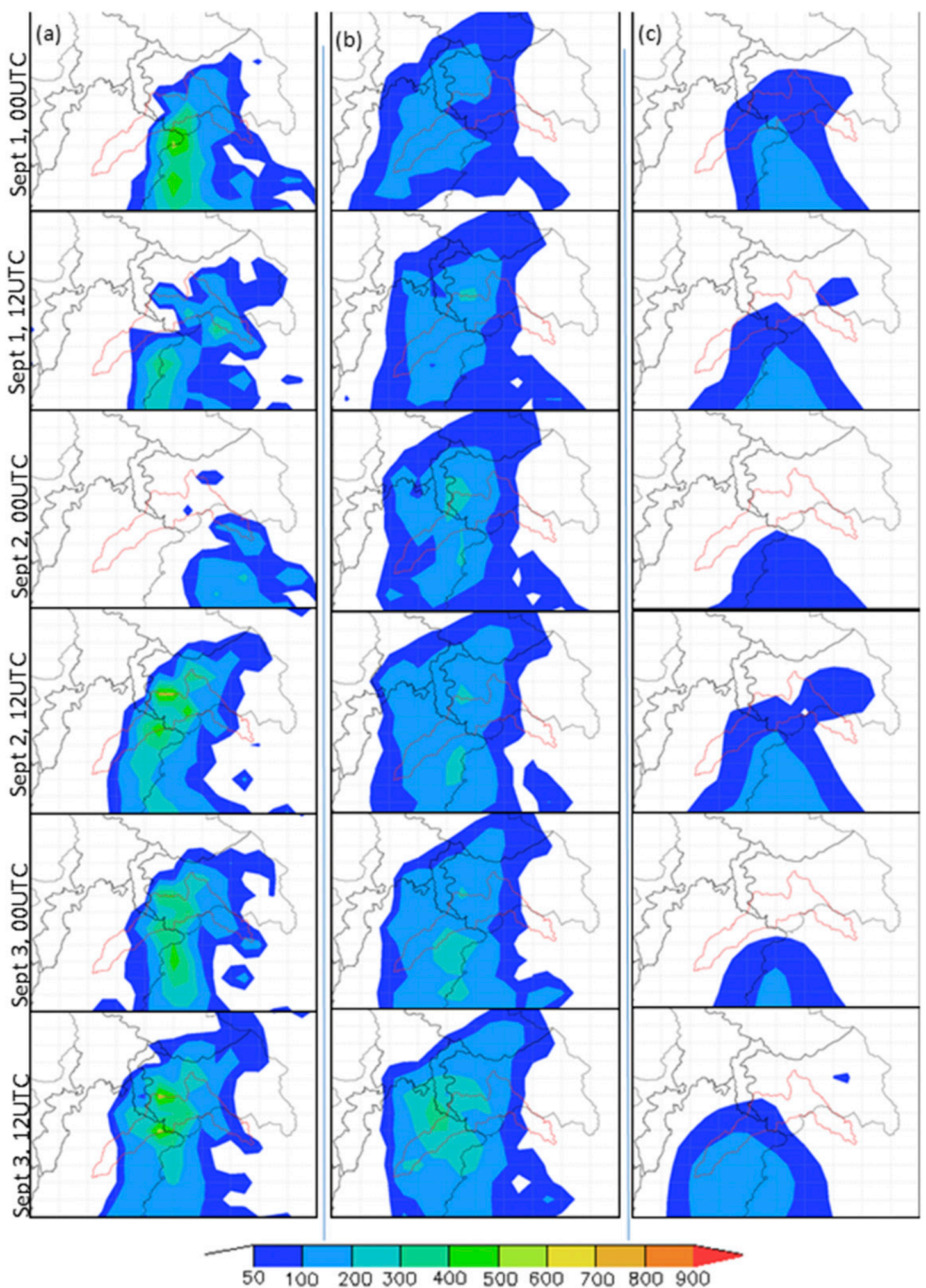

FIG. 7. Accumulated storm rainfall (from 0000 UTC 3 Sep to 0000 UTC 7 Sep 2014) forecasted by (a) NCEP-GFS, (b) ECMWF-IFS, and (c) JMA-GSM. Initial times of forecasts are given on the left side of the figure. The area enclosed by the red line indicates the CRB. 

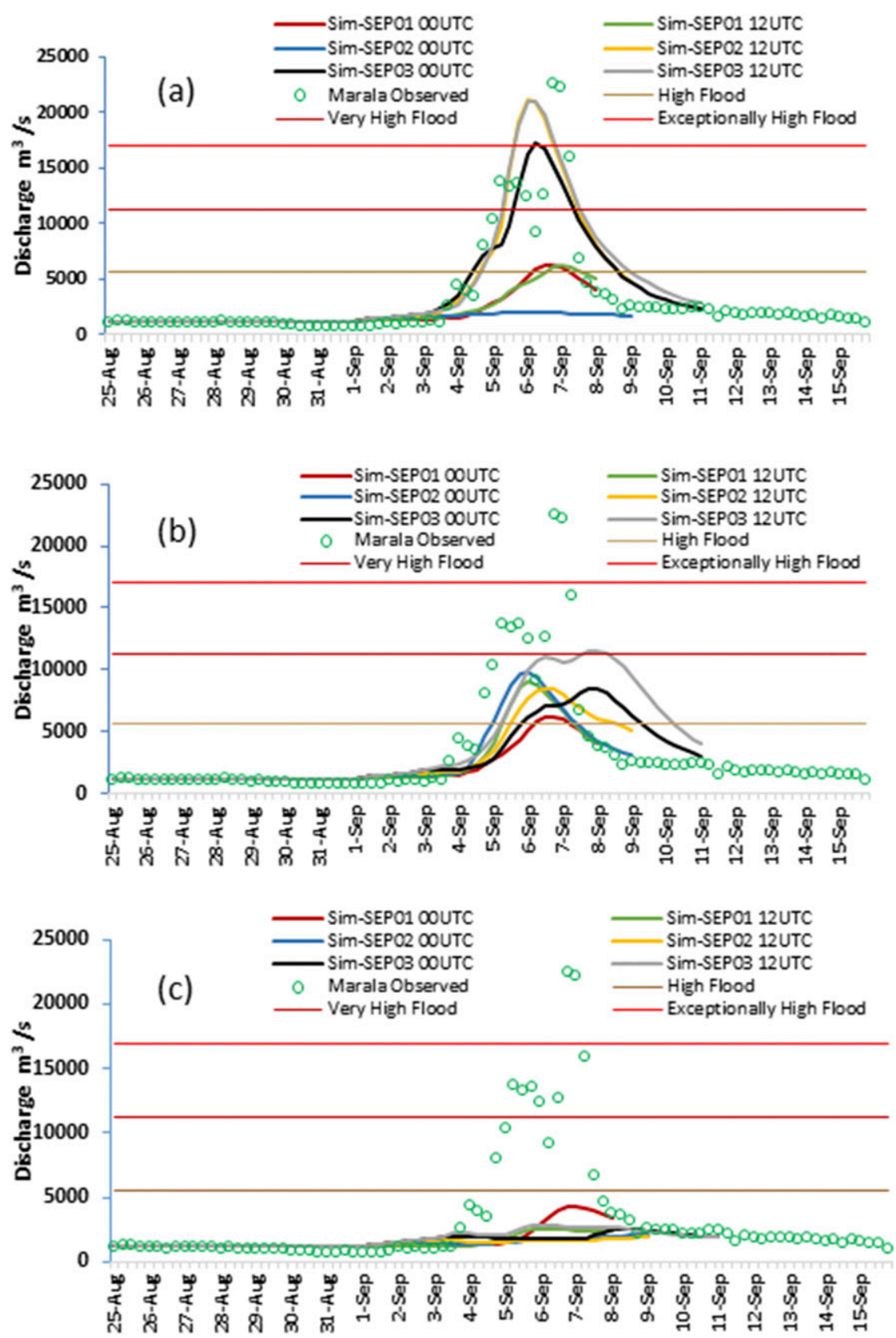

FIG. 8. Simulated hydrographs at Marala, predicted by IFAS from the precipitation forecasts of (a) NCEP-GFS, (b) ECMWF-IFS, and (c) JMA-GSM global models, with six initial times between 0000 UTC 1 Sep and 1200 UTC 3 Sep 2014 with an interval of $12 \mathrm{~h}$.

simulations causes serious hindrance to building confidence among forecasters in flood forecasting.

\section{b. Flood forecasting by using downscaled rainfall}

To improve the accuracy of forecasts, global-scale forecasts were downscaled with a regional model, WRF, at $5-\mathrm{km}$ grid intervals. Overall, 18 forecasts from the three global models were downscaled. Figure 9 shows downscaled rainfall over the CRB, taking the initial and boundary conditions from the global forecasts with the initial times from 0000 UTC 1 September to 1200 UTC 3 September at an interval of $12 \mathrm{~h}$. The intensity and spatial distributions of QPFs significantly have improved and are much higher than the global forecasts. The rainfall shifting outside the basin found in the global forecast of NCEP 0000 UTC 2 September 


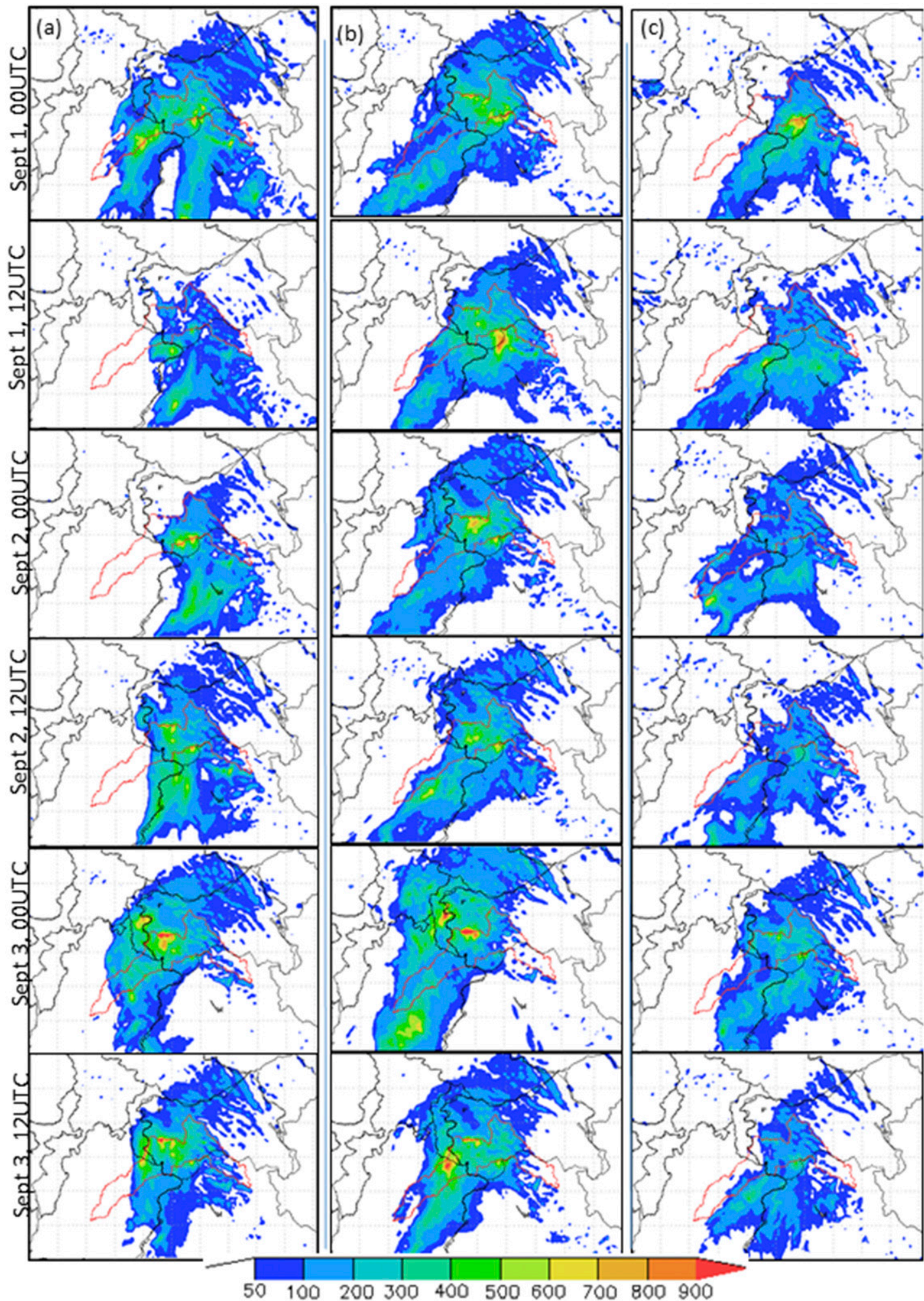

FIG. 9. Accumulated storm rainfall (from 0000 UTC 3 Sep to 0000 UTC 7 Sep 2014), downscaled at 5-km resolution using WRF, from the forecast of (a) NCEP-GFS, (b) ECMWF-IFS, and (c) JMA-GSM. Initial times of forecasts are given on left side of the figure. The area enclosed by the red dotted line indicates the CRB. 
(Fig. 7a) has been resolved after downscaling (Fig. 9a). A much larger area of the basin is covered by significant rainfall with a high intensity. ECMWF-IFS and JMA-GSM (Figs. 9b,c) rainfall has also improved in terms of extent, intensity and location after downscaling. In the JMA-GSM forecasts, a significant amount of rainfall occur outside the CRB; however, in the downscaled version, the location and intensity of rainfall have improved though the intensity remains below the observed rainfall. In this study, providing high-resolution topography and regional features to WRF significantly improved the rainfall forecasts for the CRB, since WRF has the capability of improving rainfall forecasts if regional features are resolved well (Ntwali et al. 2016).

Figure 10 shows simulated hydrographs from IFAS using downscaled rainfall. The forecasted discharges agree with the observed discharges better than those computed using the global forecasts in Fig. 8. Many of the forecasted discharges reach the exceptionally high flood level, and the time of the peak occurrence corresponds well with the observation.

In 13 out of the 18 forecasts, the predicted discharges are above the very high flood level. Furthermore, nine forecasts, issued 4-6 days prior to the flood peak, successfully predict the exceptionally high flood at the Marala headworks. The NCEP-GFS and ECMWF-IFS forecasts are better in predicting the exceptionally high flood than the JMA-GSM forecasts. However, the downscaled rainfall from JMA-GSM provides a good indication of the high flood in all the cases. Figure 11 shows a simplified color-coded box representation similar to the one used by Thielen et al. (2009), indicating the number of cases exceeding the high, very high, and exceptionally high flood thresholds. The diagram indicates that the exceptionally high flood could be predicted by using the rainfall downscaled from the global forecasts of NCEP 0000 UTC 1 September, although the signal disappear in the subsequent forecasts. However, the ECMWF-IFS forecasts remain consistent in all the forecasts, showing the exceptionally high flood signal. JMA-GSM only predicts the high and very high floods. In all the 18 cases, the high flood at Marala in the CRB is predicted with a lead time of 4-6 days.

Most of the previous studies relied on rainfall from one global NWP for flood forecasting in sparsely gauged basins. We revealed that the use of more than one type of global forecasts can provides extra advantages to make decisions on acceptance or rejection of particular forecasts for flood forecasting. The use of downscaled ECMWF forecasts along with downscaled NCEP forecasts can strengthen the reliability of the obtained flood warning, as shown in Fig. 11. Furthermore, downscaled
JMA forecasts may also improve our confidence when we consider its underestimating tendency and can be beneficial in making real-time early-warning decisions.

\section{c. Flood inundation forecasts by coupling IFAS, RRI, and high-resolution forecasted rainfall}

For the purpose of predicting inundation area due to an exceptionally high flood event, the RRI model was run using forecasted discharges at the boundary station by the IFAS model and high-resolution rainfall downscaled from global forecasts. The discharges predicted using the RRI model were validated with the observed data at the Qadir Abad headworks about $85 \mathrm{~km}$ downstream of the Marala headworks (Fig. 12). The contribution of rainfall in the lower-reach basin was found very little, and the major component of the flood peak was provided by the discharge from the boundary station. The delayed flood discharge flowed into the adjoining streams due to mild slope. In general, the RRI model performs well, provided that the flood discharge at the boundary is well forecasted by IFAS. The peak discharge forecasts from the downscaled rainfall of the three set of forecasts (NCEP 0000 UTC 1 September, NCEP 0000 UTC 3 September, and ECMWF 0000 UTC 1 September), as indicated in Fig. 12, are close to the observed peak discharge of the exceptionally high flood level. However, the model failed to reproduce the peak discharge when the boundary discharge was not predicted well as indicated by the downscaled forecasts of NCEP 0000 UTC 2 September 2014 and JMA 0000 UTC 1 September 2014 in the same figure.

Figure 13a shows the inundation extent extracted from the MODIS composite reflectance image of 14 September 2014, using MNDWI. Figure 13b shows the inundation depth and extent provided by RRI in the area between Qadir Abad and Jhang (immediately upstream of the Jhelum-Chenab confluence), using the downscaled rainfall of the NCEP 0000 UTC 1 September 2014 forecasts. Figure 13c overlaps the inundation extents by RRI forecasting and MODIS observation. In this figure, most of the red-colored area shows good agreement between them, though the inundation area from RRI forecasting is slightly overestimated (the blue color is more pronounced). This overestimation is prominent near the Qadir Abad headworks, which could result from underestimation by MODIS due to the presence of clouds. Apart from the overestimation, there are few flooded areas which are missed by the RRI model (orange color). Figure 14 illustrates the inundation by the RRI model using the downscaled ECMWF-IFS and JMA-GSM precipitation forecasts of 0000 UTC 1 September 2014. It is visibly clear that the inundation area provided by the downscaled 

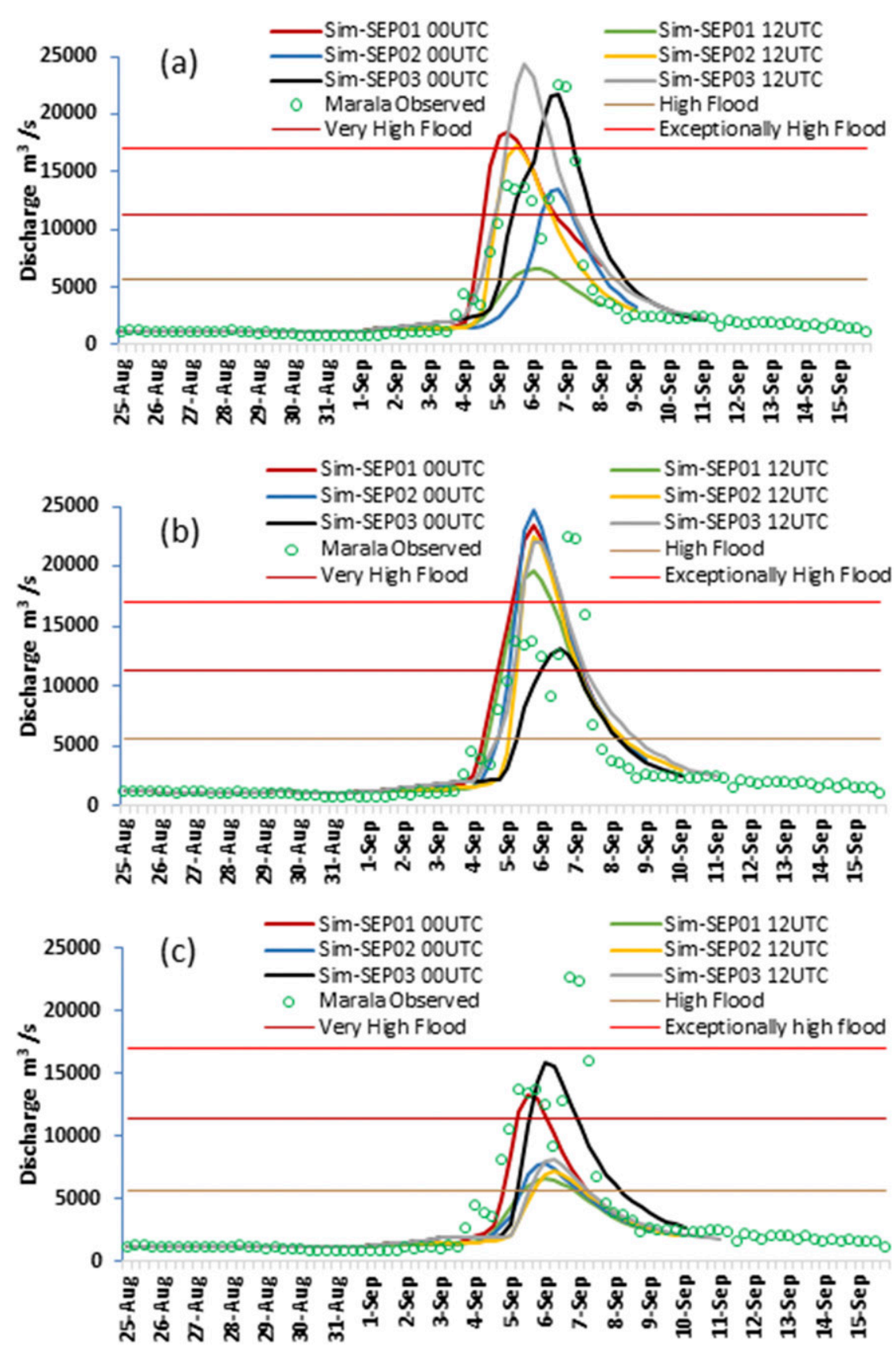

FIG. 10. Simulated hydrographs at Marala, predicted by IFAS, from the downscaled rainfall forecast of (a) NCEP-GFS, (b) ECMWF-IFS, and (c) JMA-GSM with six initial times between 0000 UTC 1 Sep and 1200 UTC 3 Sep 2014 with an interval of $12 \mathrm{~h}$.

ECMWF-IFS is close to that by the downscaled NCEP-GFS, but the inundation area by the downscaled JMA-GSM forecasts is quite smaller due to the underestimation of the IFAS-forecasted discharges at the rim station. This proved that good discharge forecasts at the rim station by IFAS can provide timely inundationarea forecasts by RRI. River geometry information is very important in RRI model calibration, and incorporating observed river cross-section data could further improve model results, which is not covered in this study. As to flood inundation area forecasts in the subsequent initial times from 1200 UTC 1 September to 1200 UTC 3 September 2014, those from the downscaled NCEPGFS and ECMWF-IFS precipitation forecasts were generally larger than those using the downscaled JMAGSM precipitation forecasts. Those results indicate that, 


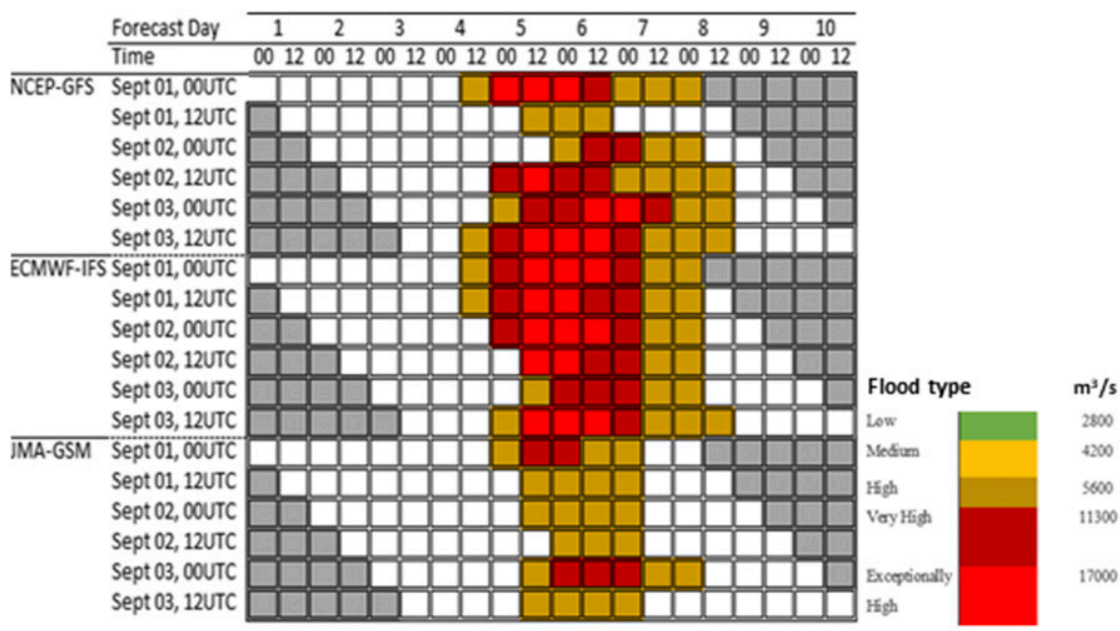

FIG. 11. Threshold exceedances of the flood peaks predicted by IFAS, using downscaled rainfall of three global models, are represented by different colors. Red, dark brown, and golden yellow colors represent exceptionally high, very high, and high flood levels, respectively.

based on an exceptionally high flood at the rim station forecasted by IFAS and driven by the downscaled ECMWF-IFS and NCEP-GFS forecasts, the discharges at the Qadir Abad headworks and the RRI-based inundation downstream of the Qadir Abad headworks could be predicted with a lead time of 4-6 days.

\section{Summary}

Exceptionally high flooding in the CRB attaining its peak on the evening of 6 September 2014, came about as a result of prolonged and orographic rainfall in the upper-reach basin. This study showed that high-resolution rainfall, downscaled from multiple global forecasts, and bias-corrected GSMaP-Gauge rainfall data could predict flood peaks in the study area with good accuracy. The study area was divided into two parts, and a kinematic wave hydrological model, IFAS, simulated floods in the upper reach of the CRB. The IFAS model was calibrated using biascorrected GSMaP-Gauged rainfall. To obtain inundation forecasts at the lower reach of the CRB, a diffusive-wave hydrological model, RRI, was employed, which was mainly driven by boundary discharges at the rim station predicted by IFAS. Rainfall forecasts from three global forecasts, namely ECMWF-IFS, NCEPGFS, and JMA-GSM, were then supplied to IFAS along with bias-corrected GSMaP-Gauge rainfall to predict discharges at the upper reach outlet (Marala headworks). Most of the predicted discharges were not in good agreement with the observed discharges, since the coarser-resolution global models could not predict rainfall intensities well in the basin. In a few cases, the rainfall was predicted outside the basin boundary.

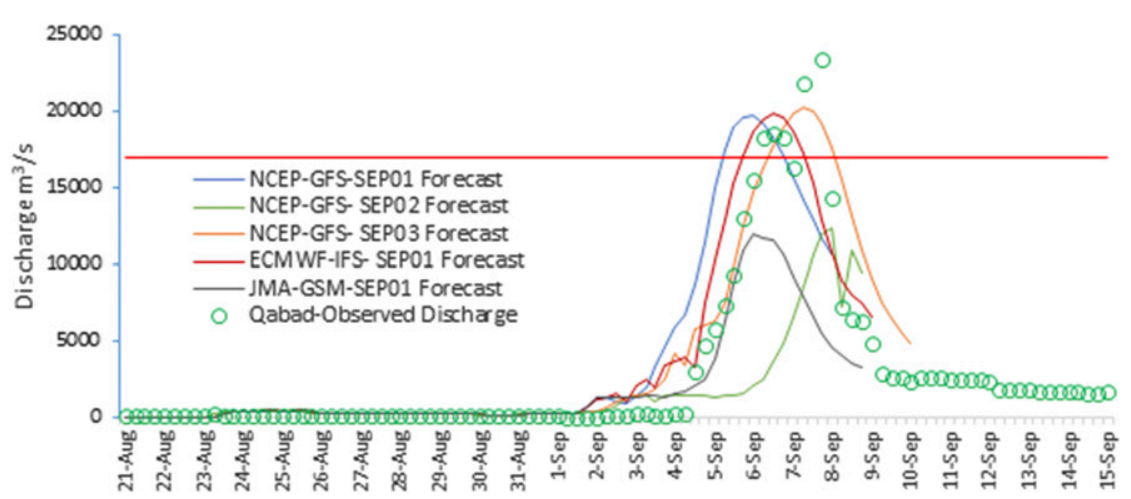

FIG. 12. The discharge peaks predicted by RRI at Qadir Abad headworks using downscaled rainfall from three global models along with boundary discharge at Marala predicted by IFAS. The red horizontal line represents an exceptionally high flood level. 


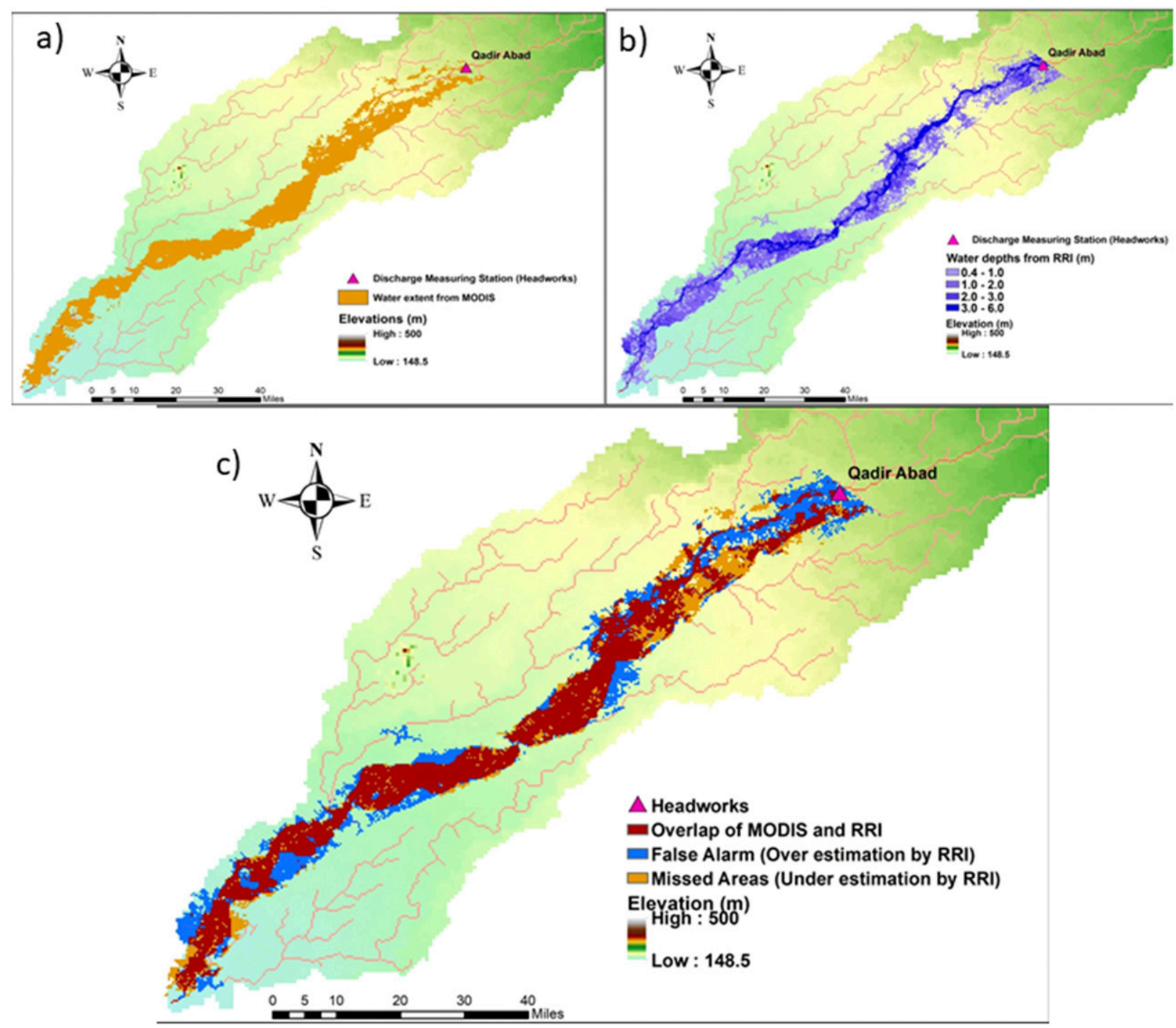

FIG. 13. (a) Water extent from MODIS image of 14 Sep 2014, (b) inundation predicted by RRI using boundary discharge at Marala from IFAS along with the NCEP 0000 UTC 1 Sep 2014 forecast, and (c) the combined image showing overlap area of RRI and MODIS extent, overestimation, and underestimation by RRI.

The precipitation downscaled from the three global forecasts by using the WRF Model showed better rainfall intensities and spatial distributions within the CRB. The hydrographs, simulated from high-resolution rainfall forecasts, also showed improved accuracy in predicting an exceptionally high flood. Furthermore, the use of multiple models enhanced the reliability of flood early warning decisions in the transboundary river basin.

Discharge forecasts at a rim station in different cases was later provided to the RRI model along with downscaled rainfall forecasts to predict flood discharges and inundation in the lower reach of the CRB. Flood discharges predicted by RRI were compared with observed hydrographs at the center of the lower reach (Qadir Abad), while the RRI-based inundation downstream of Qadir Abad was compared with those based on MODIS observation. In both comparisons, good agreement was confirmed. The results show that reliable flood forecasts at the rim station provided by IFAS can be used with RRI to predict floods and inundation in the lower reach, and this could also help evaluate hazard risk prior to flooding with a significant lead time.

Although this study focused on only one event in the CRB, it clearly indicates that multimodel precipitation forecasts coupled with hydrological models (IFAS and RRI) and bias-corrected satellite rainfall may be used to predict high floods and identify 

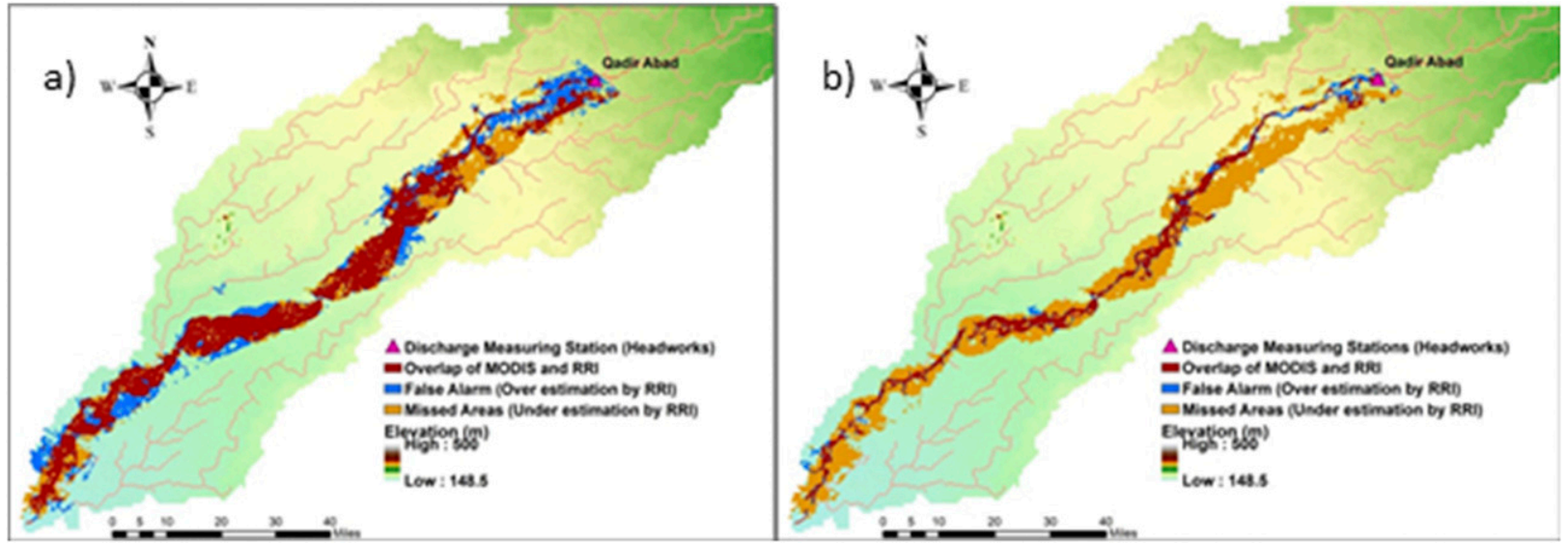

FIG. 14. Overlap area of RRI and MODIS extent along with overestimation and underestimation by RRI is shown in both panels. RRIpredicted inundation extent using downscaled rainfall of (a) ECMWF-IFS and (b) JMA-GSM initialized at 0000 UTC 1 Sep 2014 and the boundary discharge at Marala predicted by IFAS.

inundation area with an ample lead time. It may also play a major role in the issuance of reliable early warnings in order to initiate necessary preparation, timely emergency operation, and evacuation before catastrophic flood events. However, further studies on different events with various basin sizes can increase the reliability of this approach before its implementation in other river basins.

Acknowledgments. This study was conducted under the support from the Japan International Cooperation Agency (JICA) and the International Center for Water Hazard and Risk Management (ICHARM). The authors are thankful to PMD for providing rainfall and discharge data. NCEP-GFS data were provided by NCEP, and ECMWF-IFS and JMA-GSM data were obtained from TIGGE datasets. The WRF Model developed by NCAR and operated by UCAR was used for dynamic downscaling. GrADS was used to draw charts. IFAS and RRI, both developed by ICHARM-Public Works Research Institute (PWRI), were used for hydrological modeling.

\section{REFERENCES}

Alfieri, L., P. Burek, E. Dutra, B. Krzeminski, D. Muraro, J. Thielen, and F. Pappenberger, 2013: GloFAS-global ensemble streamflow forecasting and flood early warning. $\mathrm{Hy}$ drol. Earth Syst. Sci., 17, 1161-1175, https://doi.org/10.5194/ hess-17-1161-2013.

Awan, S. A., 2003: Pakistan: Flood Management - River Chenab from Marala to Khanki. World Meteorological Organization and Global Water Partnership, 31 pp., https:/www.floodmanagement.info/ publications/casestudies/cs_pakistan_chenab_full.pdf.

Aziz, A., 2014: Rainfall-runoff modeling of the trans-boundary Kabul River basin using Integrated Flood Analysis System (IFAS). Pak. J. Meteor., 10 (20), 75-81.
Bartholmes, J., and E. Todini, 2005: Coupling meteorological and hydrological models for flood forecasting. Hydrol. Earth Syst. Sci., 9, 333-346, https://doi.org/10.5194/hess-9-333-2005.

Cloke, H. L., and F. Pappenberger, 2009: Ensemble flood forecasting: A review. J. Hydrol., 375, 613-626, https://doi.org/ 10.1016/j.jhydrol.2009.06.005.

Cuo, L., T. C. Pagano, and Q. J. Wang, 2011: A review of quantitative precipitation forecasts and their use in short- to medium range streamflow forecasting. J. Hydrometeor., 12, 713-728, https://doi.org/10.1175/2011JHM1347.1.

Davolio, S., M. M. Miglietta, T. Diomede, C. Marsigli, A. Morgillo, and A. Moscatello, 2008: A meteo-hydrological prediction system based on a multi-model approach for precipitation forecasting. Nat. Hazards Earth Syst. Sci., 8, 143-159, https:// doi.org/10.5194/nhess-8-143-2008.

Haile, A. T., F. T. Tefera, and T. Rientjes, 2016: Flood forecasting in Niger-Benue basin using satellite and quantitative precipitation forecast data. Int. J. Appl. Earth Obs. Geoinf., 52, 475-484, https://doi.org/10.1016/j.jag.2016.06.021.

Hirabayashi, Y., R. Mahendran, S. Koirala, L. Konoshima, D. Yamazaki, S. Watanabe, H. Kim, and S. Kanae, 2013: Global flood risk under climate change. Nat. Climate Change, 3, 816-821, https://doi.org/10.1038/nclimate1911.

Hossain, F., N. Katiyar, Y. Hong, and A. Wolf, 2007: The emerging role of satellite rainfall data in improving the hydro-political situation of flood monitoring in the under-developed regions of the world. Nat. Hazards, 43, 199-210, https://doi.org/ 10.1007/s11069-006-9094-x.

Hou, A. Y., and Coauthors, 2014: The Global Precipitation Measurement mission. Bull. Amer. Meteor. Soc., 95, 701-722, https://doi.org/10.1175/BAMS-D-13-00164.1.

Kubota, T., T. Ushio, S. Shige, S. Kida, M. Kachi, and K. Okamoto, 2009: Verification of high-resolution satellite-based rainfall estimates around Japan using a gauge-calibrated ground-radar dataset. J. Meteor. Soc. Japan, 87A, 203-222, https://doi.org/ 10.2151/jmsj.87A.203.

Lehmann, J., C. Dim, and F. Katja, 2015: Increased recordbreaking precipitation events under global warming. Climatic Change, 132, 501-515, https://doi.org/10.1007/ s10584-015-1434-y.

Lin, Y. L., R. D. Farley, and H. D. Orville, 1983: Bulk parameterization of the snow field in a cloud model. J. Climate 
Appl. Meteor., 22, 1065-1092, https://doi.org/10.1175/ 1520-0450(1983)022<1065:BPOTSF > 2.0.CO;2.

Majid, A., and N. Akhtar, 2007: Mangla Cat-III flood forecasting procedure. Pak. J. Meteor., 4 (7), 41-54.

Miyamoto, M., M. Ono, S. Nabesaka, T. Okazumi, and Y. Iwami, 2014: Applicability of a flood forecasting method utilizing global satellite information to an insufficiently-gauged river basin: A case of a river basin in the Philippines. Proceedings 11th International Conference on Hydroinformatics, M. Piasecki, Ed., Curran Associates, 474-481.

Ntwali, D., B. A. Ogwang, and V. Ongoma, 2016: The Impacts of topography on spatial and temporal rainfall distribution over Rwanda based on WRF Model. Atmos. Climate Sci., 06, 145157, https://doi.org/10.4236/ACS.2016.62013.

Okamoto, K., T. Iguchi, N. Takahashi, K. Iwanami, and T. Ushio, 2005: The Global Satellite Mapping of Precipitation (GSMaP) project. 2005 IEEE Int. Geoscience and Remote Sensing Symp., Seoul, South Korea, IEEE, 3414-3416, https://doi.org/ 10.1109/IGARSS.2005.1526575.

Powers, J. G., and Coauthors, 2017: The Weather Research and Forecasting Model: Overview, system efforts, and future directions. Bull. Amer. Meteor. Soc., 98, 1717-1737, https://doi.org/ 10.1175/BAMS-D-15-00308.1.

Rahman, G., M. M. Anwar, M. Ahmed, H. Ashraf, and U. Zafar, 2017: Socio-economic Damages caused by the 2014 Flood in Punjab Province, Pakistan. Proc. Pak. Acad. Sci., 54B (4), 365-374.

Ray, K., S. C. Bhan, and B. K. Bandopadhyay, 2015: The catastrophe over Jammu and Kashmir in September 2014: A meteorological observational analysis. Curr. Sci., 109 (3), 580-591.

Riaz, M., A. Aziz, and S. Hussain, 2017: Flood forecasting of an ungauged trans-boundary Chenab River basin using distributed hydrological model Integrated Flood Analysis System (IFAS). Pak. J. Meteor., 13 (26), 51-62.

Roberts, N. M., S. J. Cole, R. M. Forbes, R. J. Moore, and D. Boswellc, 2009: Use of high-resolution NWP rainfall and river flow forecasts for advance warning of the Carlisle flood, north-west England. Meteor. Appl., 16, 23-34, https://doi.org/10.1002/met.94.

Sayama, T., G. Ozawa, T. Kawakami, S. Nabesaka, and K. Fukami, 2012: Rainfall-runoff-inundation analysis of the 2010 Pakistan flood in the Kabul River basin. Hydrol. Sci. J., 57, 298-312, https://doi.org/10.1080/02626667.2011.644245.

Shrestha, M. S., K. Takara, T. Kubota, and S. R. Bajracharya, 2011: Verification of GSMaP rainfall estimates over the central Himalayas. J. Japan Soc. Civil Eng. Ser B1, 67, I-37-I-42, https://doi.org/10.2208/jscejhe.67.I_37.

Skamarock, W. C., J. B. Klemp, J. Dudhia, D. O. Gill, D. M. Barker, W. Wang, and J. G. Powers, 2005: A description of the Advanced
Research WRF version 2. NCAR Tech. Note NCAR/TN468+STR, 88 pp., https://doi.org/10.5065/D6DZ069T.

Sugiura, T., T. Kawakami, G. Ozawa, K. Fukami, J. Magome, and S. Nabesaka, 2010: Experimental application of flood forecasting system (IFAS) using satellite-based rainfall. Proceedings of 9th International Conference on Hydroinformatics, J. Tao, Q. Chen, and S.-Y. Liong, Eds., Chemical Industry Press, 1786-1793.

Sugiura, A., S. Fujioka, S. Nabesaka, T. Sayama, Y. Iwami, K. Fukami, and S. Tanaka, 2013: Challenges on modelling a large river basin with scarce data: A case study of the Indus upper catchment. MODSIM2013, 20th International Congress on Modelling and Simulation, Modelling and Simulation Society of Australia and New Zealand, 2346-2352, https://www.mssanz.org.au/modsim2013/L1/sugiura.pdf.

Thielen, J., J. Bartholmes, M. H. Ramos, and A. de Roo, 2009: The European Flood Alert System - Part 1: Concept and development. Hydrol. Earth Syst. Sci., 13, 125-140, https://doi.org/ 10.5194/hess-13-125-2009.

Ushio, T., T. Matsuda, T. Tashima, T. Kubota, M. Kachi, and S. Yoshida, 2013: Gauge Adjusted Global Satellite Mapping of Precipitation (GSMaP_Gauge). 29th Int. Symp. on Space Technology and Science, Nagoya City, Japan, JAXA, Paper 2013-n-48, 4 pp., https://archive.ists.or.jp/upload_pdf/2013n-48.pdf.

Ushiyama, T., T. Sayama, Y. Tatebe, S. Fujioka, and K. Fukami, 2014: Numerical simulation of 2010 Pakistan flood in the Kabul River basin by using lagged ensemble rainfall forecasting. J. Hydrometeor., 15, 193-211, https://doi.org/10.1175/ JHM-D-13-011.1.

Webster, P. J., and Coauthors, 2010: Extended-range probabilistic forecasts of Ganges and Brahmaputra floods in Bangladesh. Bull. Amer. Meteor. Soc., 91, 1493-1514, https://doi.org/10.1175/2010BAMS2911.1.

$\mathrm{Xu}, \mathrm{H} ., 2006$ : Modification of normalised difference water index (NDWI) to enhance open water features in remotely sensed imagery. Int. J. Remote Sens., 27, 3025-3033, https://doi.org/ 10.1080/01431160600589179.

Yan, H., and W. A. Gallus, 2016: An evaluation of QPF from the WRF, NAM, and GFS models using multiple verification methods over a small domain. Wea. Forecasting, 31, 13631379, https://doi.org/10.1175/WAF-D-16-0020.1.

Yu, W., E. Nakakita, S. Kim, and K. Yamaguchi, 2016: Impact assessment of uncertainty propagation of ensemble NWP rainfall to flood forecasting with catchment scale. Adv. Meteor., 2016, 1384302, https://doi.org/10.1155/2016/ 1384302. 